o wychowaniu: S. Łempickiego i K. Sośnickiego. Pojawiaja się także M. Ziemnowicz, M. Kreutz i, po raz kolejny, K. Twardowski. Rozważania K. Szmyda kończy siódmy rozdział, będący jednocześnie próbą konkluzji i oceny lwowskiego środowiska nauk o wychowaniu.

Bibliografia zebrana przez autora na końcu pracy jest imponujaca, chociaż przedstawiona jest jedynie w wyborze. K. Szmyd wnikliwie zbadał zasoby archiwów, niestety jedynie ukraińskich, może należało także przejrzeć zbiory, np. wrocławskiego Ossolineum? Zastanawia mnie również fakt doboru opracowań; autor bowiem podaje je w wyborze, czyni to jednak dublując niektóre pozycje, np. podaje tytuły prac zbiorowych (pokonferencyjnych), a zaraz potem wymienia poszczególne artykuły $w$ nich zawarte. Podobnie jest $\mathrm{z}$ czasopismami: najpierw sa one wymienione (bez roczników, niestety) jako osobna kategoria bibliografii, a następnie w opracowaniach odnaleźć można konkretne prace w tychże czasopismach drukowane. Do źródeł drukowanych zaliczyłabym także, inaczej niż zrobił to autor pracy, wymienione w opracowaniach, dzieła twórców nauk o wychowaniu, pisane jeszcze często w wieku XIX.

Czy autorowi udało się zrealizować postawione sobie na poczatku pracy cele? Czy motywy, jakimi kierował się przy wyborze tematu okazały się wystarczające? Czy dzieło K. Szmyda, „Twórcy nauk o wychowaniu w środowisku akademickim Lwowa (1860 - 1939)" jest nowatorskie i wypełnia jakąkolwiek lukę w bibliografii?

Na wszystkie te pytania należy odpowiedzieć twierdząco. Można nawet stwierdzić, iż autor zdołal poruszyć znacznie szerszą problematykę, niźli wskazuje tytuł pracy, bo oto nie mamy przed oczyma jedynie naszkicowanych kilku portretów twórców nauk o wychowaniu we Lwowie, ale obszerną rozprawę, będącą udaną rekonstrukcja środowiska akademickiego i tradycji pedagogicznych w wielokulturowym i fascynujacym miejscu, jakim była stolica Galicji. Każda społeczność akademicka powinna postarać się, by prace tego typu stały się jej udziałem.

\section{Edyta Glowacka-Sobiech}

\title{
Iwona Wendreńska, Dydaktyka ogólna jako przedmiot kształcenia nauczycieli w Drugiej Rzeczypospolitej (1918 - 1939), Wydawnictwo Uniwersytetu Sląskiego, Katowice 2003, ss. 171
}

W dobie aktualnych przemian społecznych, politycznych, kulturowych $\mathrm{i}$ innych zmienia się spojrzenie na nauczyciela. Często współczesnemu nauczycielowi wyznacza się rolę promotora przemian jakościowych w edukacji, w kształtowaniu charakteru nowego pokolenia. Fakt ten pociaga za sobą m.in. przewartościowanie dotychczas pożadanych kompetencji zawodowych nauczyciela. Oczekiwania i wymagania wobec nauczycieli sa i prawdopodobnie będą coraz większe. Tymczasem obowiązujące modele kształcenia, nastawione głównie na wyposażenje przyszłych nauczycieli w wiedzę teoretyczną $\mathrm{z}$ określonej dziedziny wydają się niewystarczajace dla ich spełnienia. W dyskusjach nad problematyką przygotowania nauczycieli do wypełniania roli zawodowej, nabywania określonych kompetencji pojawiaja się coraz częściej postulaty dotyczące konieczności wprowadzenia zmian nie tylko w siatkach godzin poszczególnych instytucjonalnych form kształcenia nauczycieli, ale także w celach, treściach, technologii kształcenia różnych przedmiotów, a zwłaszcza dydaktyki ogólnej. Rozprawa Iwony Wendreńskiej pt. „Dydaktyka ogólna jako przedmiot kształcenia nauczycieli w Drugiej Rzeczypospolitej (1918 - 1939)" włacza się w nurt refleksji nad dydaktyką ogólną jako przedmiotem kształcenia nauczycieli szkół ogólnokształcących. Praca ma charakter monografii historyczno-pedagogicznej i dotyczy dydaktyki ogólnej jako przedmiotu 
kształcenia nauczycieli zarówno w seminariach nauczycielskich, liceach pedagogicznych, pedagogiach, jak i niektórych szkołach wyższych, tj. na Uniwersytecie Jagiellońskim, Uniwersytecie Poznańskim, Uniwersytecie Warszawskim oraz w Wolnej Wszechnicy Polskiej w okresie międzywojennym. Wybór powyższych uczelni, jak pisze sama autorka, był spowodowany faktem, iż dopracowały się one w odróżnieniu od innych - pełnego programu studiów nauczycielskich, a także sposobu jego realizacji.

Praca ma przejrzysty układ. Składa się z czterech logicznie powiązanych ze sobą rozdziałów. Rozdział pierwszy wprowadzający - dotyczy realizacji dydaktyki ogólnej jako przedmiotu kształcenia nauczycieli szkół ogólnokształcących na ziemiach polskich od połowy XIX do poczatku XX stulecia. Dokonując wnikliwej analizy i oceny materiału źródłowego autorka stwierdziła, że dydaktykę ogólną w zakładach kształcenia nauczycieli w owym czasie realizowano w bardzo szczupłym zakresie i niejednokrotnie podawano w dogmatycznej formie. Konstrukcja i treść programu nauczania dydaktyki ogólnej, a także podręczniki do tego przedmiotu opierały się na wzorach metodologicznych herbartyzmu.

$W$ rozdziale drugim z kolei, autorka trafnie przedstawiła najważniejsze teoretyczne i instytucjonalne uwarunkowania nauczania przedmiotu „dydaktyka ogólna" w Drugiej Rzeczypospolitej. Zaliczyla do nich: sytuację polityczna, społeczną i oświatowa państwa polskiego w latach 1918 - 1939; rozwój instytucjonalnych form kształcenia kadr nauczycielskich oraz rozwój dydaktyki jako nauki w ,międzywojniu".

Rozdział drugi stanowił punkt wyjścia dla kluczowych dociekań prowadzonych w rozdziale trzecim prezentowanej rozprawy. Odnosily się one do miejsca i roli dydaktyki ogólnej na tle innych pedagogicznych przedmiotów kształcenia nauczycieli szkół ogólnokształcących w okresie Drugiej Rzeczypospolitej. Celem rozdziału drugiego było również ukazanie przeobrażeń w celach, treściach, metodach i formach nauczania dydaktyki ogólnej w instytucjach kształcących nauczycieli szkół ogólnokształcacych. Badania prowadzone nad wskazanymi powyżej zagadnieniami wykazały m.in., że $w$ porównaniu $z$ realizacją dydaktyki ogólnej w okresie zaborów, oferta programowa tego przedmiotu w Drugiej Rzeczy- pospolitej była znacznie bogatsza, obejmowała nowe wartościowe problemy i treści. Jej „kształt” wyznaczala nie tylko koncepcja herbartowska, ale także hasła ,nowej szkoły" i idee pedagogiki kultury. Warto podkreślić, że w rozdziale trzecim autorka pokazala interesujące rozwiązania praktyczne w zakresie form i metod nauczania przedmiotu dydaktyka ogólna. Dotyczyły one na przykład postulatu stosowania sposobów i form pracy sprzyjajacych kształtowaniu aktywności poznawczej słuchaczy, opartej na poszukiwaniu odpowiedzi nie tylko na pytanie: Jak jest?, ale także: Dlaczego tak jest? Sami nauczyciele przedmiotów pedagogicznych, pracujący w instytucjach przygotowujących przyszłych nauczycieli, byli zobligowani do doskonalenia swoich kompetencji zawodowych poprzez wspólpracę z ogniskami metodycznymi, uczestniczenie w kursach wakacyjnych, zjazdach pedagogicznych organizowanych przez władze szkolne. Treść rozdziału trzeciego została wzbogacona o tabele, które zapewniaja lepszą orientację w czytanym tekście.

Przytoczone w poszczególnych rozdziałach wyniki badań historyczno-pedagogicznych znalazły interesujaca kontynuację w rozdziale czwartym (ostatnim) niniejszej rozprawy. W rozdziale tym autorka próbowała bowiem odpowiedzieć na pytanie: „Czy i w jakim zakresie dorobek dydaktyki ogólnej jako przedmiotu nauczania w Drugiej Rzeczypospolitej może stanowić inspirację dla współczesnej edukacji nauczycielskiej?" Czy jej się to udało? Ocenę pozostawiam czytelnikom.

$\mathrm{Na}$ zakończenie należy podkreślić, ze książka „Dydaktyka ogólna jako przedmiot kształcenia nauczycieli w Drugiej Rzeczypospolitej (1918-1939)", oparta na szerokiej podstawie źródłowej, jest ważnym przyczynkiem do szerszej dyskusji nad znaczeniem przedmiotu: dydaktyka ogólna we współczesnej edukacji nauczycielskiej. Próba odnalezienia pomostu pomiędzy przeszłością i teraźniejszościa sytuuje niniejszą rozprawę $w$ najnowszym nurcie uprawiania historii wychowania, zgodnie z którym badania historyczne maja nie tylko dostarczać wiedzy o przeszlości, ale przede wszystkim przyczyniać się do efektywniejszego rozwiazywania współczesnych problemów edukacyjnych. Stąd też prace Iwony Wendreńskiej można polecić zarówno historykom oświaty, nauczycielom, studentom, jak 
i tym wszystkim, którzy interesuja się problematyka przemian $w$ polskiej rzeczywistości szkolnej.

\section{Violetta Rodek}

${ }^{1}$ Por. np. Cz. Majorek, Warsztat badawczy historyka wychowania dziejów najnowszych [w:] Stan i perspektywy historii wychowania, red. W. Jamrożek,
Poznań 1995, s. 63; S. Michalski, Geneza i rozwój historii wychowania [w:] Nauki pedagogiczne w Polsce, tradycja, wspótczesność, przyszlość. Materiaty z konferencji, red. S. Michalski i R. Ossowski, Bydgoszcz 1994, s. 20 -21; B. Ratuś, Zwiazki historii i teorii wychowania (dylematy $w$ okresie zmiany ustroju w Polsce) [w:] Z problematyki metodologicznej teorii wychowania, red. A. Tchorzewski, Bydgoszcz 1994, s. 111 .

\section{Adam Winiarz, Szkolnictwo Księstwa Warszawskiego i Królestwa Polskiego (1807-1831), Lublin 2002, ss. 586}

Dzieje szkolnictwa w Księstwie Warszawskim i Królestwie Polskim doby konstytucyjnej stanowia jedna z najbardziej interesujacych kart polskiej oświaty XIX wieku. Praca Adama Winiarza pt. „Szkolnictwo Księstwa Warszawskiego i Królestwa Polskiego (1807-1831)" jest pierwsza próbą tak szerokiego ujęcia tytułowego problemu. O oryginalności i wyjątkowym charakterze pracy decyduje przede wszystkim fakt, iż omawiane przez autora zagadnienia nie posiadały dotą pełnego opracowania monograficznego. Autor podjął się więc trudnego i mozolnego zadania ukazania złożonej problematyki szkolnictwa Księstwa Warszawskiego i Królestwa Polskiego doby autonomicznej.

Obszerny, bo liczący 586 stron materiał ujęty został w 5 rozdziałach. W ich ramach autor prezentuje całość zawiłej problematyki szkolnej tego okresu.

Dodatkowym atutem pracy, uzupełniającym zawarte w niej treści sa: streszczenie w języku angielskim, wykaz źródel $\mathrm{i}$ literatury, indeks osób, indeks nazw geograficznych oraz wykaz skrótów używanych w tekście. Przypisy odnoszące się do treści poszczególnych rozdziałów, zapewne $\mathrm{z}$ uwagi na pokaźna ich liczbę, zostały umieszczone na końcu każdego $z$ rozdziałów.

Precyzyjność i dociekliwość badawcza autora sprawiła, że recenzowana praca stanowi pod każdym względem dzieło dojrzałe i wiarygodne. O rzetelności przeprowadzonych badań świadczy niewatpliwie imponujący wręcz zasób źródeł wykorzystany przez autora. $\mathrm{Z}$ uwagi na ich różnorodność zasługują one na szersze omówienie.
Bazę źródłową opracowania stanowią materiały archiwalne, zarówno państwowych, jak i kościelnych archiwów z terenu Polski. Prezentowane w pracy źródła rękopiśmienne dowodza, iż autor przeprowadził również kwerendę zbiorów rękopiśmiennych bibliotek. Oprócz wspomnianych źródeł, w pracy wykorzystane zostały liczne źródła drukowane, takie jak: Dzienniki Praw Księstwa Warszawskiego i Królestwa Polskiego, Dzienniki Departamentowe i Wojewódzkie, zbiory przepisów Izby Edukacyjnej, Komisji Rzadowej Wyznań Religijnych i Oświecenia Publicznego, Komisji Rzadowej Spraw Wewnętrznych i Policji oraz Komisji Rządowej Sprawiedliwości. Wykorzystano także programy popisów szkolnych z lat 1807 - 1835. Uzupelnieniem materiałów rękopiśmiennych i źródel drukowanych jest prasa i czasopisma badanego okresu, podręczniki i ksiażki używane w szkołach oraz literatura pamiętnikarska i wspomnieniowa.

$\mathrm{Na}$ uwage zasługuje także fakt, iż tytuły podręczników (także innych książek używanych w szkołach), programów popisów publicznych uczniów i ówczesnych drukowanych dokumentów zostały podane $\mathrm{w}$ przypisach i bibliografii z zachowaniem oryginalnej pisowni.

Obok walorów naukowych zaleta pracy jest również jej przejrzysty i logiczny układ. Autor trafnie zdecydował się nadać strukturze pracy układ chronologiczno-problemowy, co pozwoliło na czytelne przedstawienie złożonej problematyki szkolnictwa Księstwa Warszawskiego i Królestwa Polskiego doby autonomicznej. 